\title{
Interfaith Dialogue and Humanization of the Religious Other: Discourse and Action
}

\author{
Jenn Lindsay \\ John Cabot University, Rome, Italy \\ <jlindsay@johncabot.edu>
}

\begin{abstract}
Humanization is a frequently invoked goal of interfaith dialogue-but what does it mean to dialoguers to be "human," let alone to make each person more human? This article takes a close look at the common discourses of interfaith dialoguers, and how those discourses are translated into action. Drawing on observed vignettes and reflections from ethnographic interviews across geopolitical contexts, the article conceptualizes humanization as a discursive object of the interfaith society that dialoguers invoke to enhance group solidarity and express collective identity in the form of their sacred values. By frequently invoking the concept of humanization, interfaith dialogues signal to each other that they are uniting around a common goal. Specifically, the article investigates normative discourses regarding "humanization" of the religious other and how the practice of exchanging narratives facilitates humanization and the cultivation of empathy. Through this data we can see that "humanization" is a common discursive goal of dialoguers. In Italy, humanization is a matter of disconfirming stereotypes and alleviating ignorance across social divides, whereas in the Middle East humanization intensifies into a commitment to not physically harm the other, who is recognized through the course of intergroup engagement as sharing a common ground of experience and complexity with the other. Dialoguers say humanization can be achieved through non-discursive relational practices such as artistic collaboration, shared silence, humor or cognitive re-framing, but most often through narrative storytelling.
\end{abstract}

Keywords: interfaith dialogue, humanization, discourse, empathy, Italy, comparative ethnography, Israel-Palestinian

\section{Introduction}

A Catholic priest serving in the Pontifical Council for Interreligious Dialogue remarked, "The closest interfaith relationship is inspired by shared values, which humanize people to each other." Humanization is a frequently invoked concept in the interreligious world - but what does it mean that shared values served to 
humanize these neighbors? What does it mean to dialoguers to be "human," let alone to make each person more human? This article takes a close look at the common discourses of interfaith dialoguers, and how those discourses are translated into action. Drawing on observed vignettes and reflections from ethnographic interviews, the article conceptualizes humanization as a discursive object of the interfaith society and analyzes the ways that the interfaith society defined and enacts it. Specifically, the article investigates normative discourses regarding "humanization" of the religious other and how the practice of exchanging narratives facilitates humanization and the cultivation of empathy.

\section{Methodology}

This analysis is based on 18 months of ethnographic participant-observation, primarily at interfaith organizations in Rome, chiefly the interfaith magazine and program office Confronti and then in about 12 other interfaith groups. ${ }^{*}$ I held 69 semi-structured 2-hour interviews in Rome, mostly in Italian and sometimes in English. I engaged ethnographic methodologies of participant-observation, interviews, and photo elicitation. Interviews were semi-structured, meaning that questions were often asked out of order,

* I was initially introduced to Confronti through research supported by a pre-dissertation fellowship from the Robert Lemelson Foundation and the Society for Psychological Anthropology. delved into more deeply if needed, or discarded if they seemed irrelevant. Interview questions, developed both in the pre-research preparation process and during fieldwork in a reflective and interrogative stance,[1] were asked during approximately twohour interviews with individuals in the four sub-sample groups referred to as Confronti staff, Confronti affiliates, Roman interfaithers, and Typical Romans. Confronti staff were interviewed twice over 9-month intervals, which allowed for a sense of change in the narrative data. "Roman interfaithers" and "Typical Romans" were contacted through "snowball sampling,"[2][3] a recruitment method that employs research into participants' social networks to access specific populations.[4]

These questions about humanization and mutual recognition takes us from Rome to Israel and Palestine. On three separate occasions over my 18-month fieldwork period I was able to travel with Confronti journalists to Israel and the Palestinian Territories to research dialogue practices there. On another occasion, for the Semi di Pace project Confronti sponsored a group of Israelis and Palestinians to tour in Italy and conduct public dialogues and seminars in Italian high schools about the Israel-Palestine conflict. This chapter draws on ethnographic data from those encounters, as well as interviews conducted when I traveled 
with Confronti, incorporating 30

interviews of dialoguers in Israel and Palestine. A rich transcultural data set about the construct of humanization will enrich understanding of what interfaithers mean by this word.

\section{The Discourse of Sacred Values}

I interviewed a prominent Italian imam who used the phrase "universal values" several times in his description of interfaith engagement. He said that interfaith engagement "doesn't reverse Western trends of working, eating, enjoying consumer trends - but it brings depth to everything we do, and it brings a consciousness of values." This imam felt that the change dialogue can bring to society is "a movement of universal values that are shaped and upheld by all communities in all regions, interreligious values connecting people to the sacred dimension of life, steering people to the richness available to us, and our need for it."

I asked the imam to define universal values. He said, "Universal values are the sacred values of any human that respects richness of knowledge, the principal of justice, and love as an essence of relation between humans. Without these we are lost. Without these we are not human. They're universal because they belong to the essence of every human being. The unity of God inspired creation and roots these values. If you ignore them, you ignore nature."
Of course, the goal to "bring a consciousness of values" is very abstract. As soon as such aims are particularized into concrete strategies and measurable items, the universality of "universal values" is lost. The more universalized and abstract is the expression of such aims as unity, transformation, humanization and mutual recognition, the more broadly applicable they become, and the more seemingly "achievable." These goals remain most morally forceful when they are invoked in broad and inclusive verbiage. Since interfaith discourse on unity, transformation and mutuality is constitutive of the interfaith society, the abstractness of its expression is a necessary quality.

The imam's notion of "universal values" can be compared to French sociologist Émile Durkheim's understanding of sacred values. Durkheim wrote that religion is a social fact, so it must have a social basis. In fact, for Durkheim, religion is not merely "a" social fact, but it is the primal and originary social fact - an experience transcending the physically isolated, selfish ego which impels commitment to the moral, eternal collective. As Durkheim saw in religion, the invocation of unifying beliefs and sacred values bonds the community together. Understood in a Durkheimian framework, interfaith dialogue is a sort of "church" of values, where all can transcend the religious and cultural 
difference and worship their common axiological totems, thereby transcending their individual differences. The interfaith society "is the objective, universal, and eternal cause of those sui generis sensations of which religious experience is made." Dialogue evokes a moral force and "awakens that feeling of support, safety, and protective guidance which binds the man of faith to his cult. It is this reality that makes him rise above himself."[5]

At the Rome meeting of the International Council of Christians and Jews, a rabbi affirmed the Durkheimian view of religious community when he told me that, in his congregation, "interfaith is the new religion for people on the edge of their religions. For people who are more comfortable talking to people on the outside." A Zen Buddhist monk of Dialogo Interreligioso Monastico told me, "Dialogue is a little like a religion, it is seen as the only way, in fact it really is the only way to help the problems of humanity, for people come to a fuller experience of what they don't understand." And at the annual meeting of Pontifical Institute for the Study of Arabic and Islam, I told a participant I was studying interfaith dialogue in Rome and he said, "An interfaith gathering quickly becomes a new religion, with its own form of communication, its own moral system."

With comments like this it became increasingly obvious that it is useful to view interfaith dialogue as a sort of "religion" in Durkheimian terms - with denominations, schisms, hierarchies, and a history that enables each member to be a part of something that is greater than the sum of its parts. ${ }^{* *}$ As in the Durkheimian definition of religion, interfaithing in Rome consists of a network of people practicing interfaith encounters, who all together constitute a moral community ritualistically united around their ideals, who set apart sacred values like pluralism, social change, and humanization from such profane forces as prejudice, violence and consumerism.

In their conversations, interfaith dialoguers frequently articulate their sacred values, which are moral imperatives that are transcendental, inviolable, and ultimate. Their sacred values represent the best possible world, a sort of human paradise, one that the interfaithers feel tasked with constructing. The interfaithers, by talking about and enacting their sacred values through the canopy of dialogue methods, develop a common language that binds them together.

But the sacred values of interfaithers are not just clichèd expressions. These phrases become potent symbols, "discursive objects"

\footnotetext{
** Collective representations are the product of an immense cooperation that extends not only through space but also through time; to make them, a multitude of different minds have associated, intermixed, and combined their ideas and feelings; long generations have accumulated their experience and knowledge. A very special intellectuality that is infinitely richer and more complex than that of the individual is distilled in them" Durkheim 1912.
} 
that hold a power greater than the sum of its constituent letters. In the following pages, I will explain how humanity and humanization, as sacred values with many vectors of meaning, is a universalistic, essentialist discursive object of the interfaith community, invoked by dialoguers to enhance group solidarity and express collective identity.

\section{The Sacred Value of "Humanity"}

As with the totems of pluralism and social change, "humanity" stands as a sacred value that the interfaith society invokes as a gesture of identity and solidarity. To continue this Durkheimian line of thought, it should be noted that Durkheim himself conjectured that the sacred value of "humanity" would hold society together without the binding force of religion.[6] Dialoguers themselves invoke "humanity" as an aspirational ideal, and humanity is contrasted with the natural tendency to conflict and social bias that dialoguers say is found among human beings. This chapter delves into the various meanings that dialoguers assign to the notion of humanization, and what it means to be fully human. Their perspective is most clearly encapsulated by educational theorist Paolo Freire, who views the process of humanization as an "ontological vocation," [7] an aspirational journey that sets humans apart from other sentient creatures. After establishing the constructed meanings of humanity, we will look specifically at the methodology of narrative - in both the sense of storytelling and of grappling with the multiple narratives that can arise in a single group over a shared experience - and how the methodology of narrative is seen by the interfaith society to foster the process of humanization - and how, as uttered by a representative of Combatants for Peace in Israel, "Dialogue is a humanization process."

\section{What is Humanization?}

"Humanization" is a frequently invoked construct in the interreligious world. But what does it mean for dialoguers to make each other "more human"? This section investigates normative discourses regarding how dialogue is supposed to lead to humanization of the religious other. It explores the various meanings that dialoguers assign to humanization and what it means to them to be fully, very, or more human. The basic argument here is that dialoguers invoke humanity as an aspirational ideal and a discursive object, whereby to be human is contrasted to being Homo sapiens, with its natural tendency toward conflict and social bias.

One might say that the direct opposite of humanization is dehumanization. Dehumanization can run the gamut from active oppression and violence, or, in its lighter form, to stereotyping and silencing. This 
lighter form of suppression might be better termed non-humanization. It would be extreme to assert that those who do dialogue in Rome are moving from a stance of dehumanization toward re-humanization. In Rome, dialogue purports to heal widespread popular tendencies toward nonhumanization that surface in the form of assumptions, stereotypes and systemic discrimination, whereby others are viewed not as individuals but in terms of depersonalized social categories. The challenges to humanization in Italy seem primarily a matter of decreasing ignorance and raising the level of culture so that people can think more "humanistically" about social difference and become more informed citizens. Sometimes a simple explanation of personal customs can go a long way in avoiding "dehumanizing" negative stereotyping.

For example, during my fieldwork I spoke to a Christian couple who said Jews are strange and very rude. I asked why they thought so, and they told me a story of hosting an Orthodox Jewish family for an afternoon visit in their home. The Jews, to keep kosher, brought their own food, drink and paper plates. The host family was very offended by this. They understood the separate food, but for them separate plates were inconceivable. They took it as an insult against their basic way of life. It sounded to me like the host family did not know the subtleties of kashrut $^{* * *}$ and that the Jews did not take the time to explain this aspect of their religion. Thus, the host family was left with a very poor impression of religious Jews.

I explained to the couple the concept of kashrut and related to them that I myself - also Jewish — was once confused and offended when an Orthodox Jewish friend refused to drink the tap water in my home, but that my friend helped me understand his commitment to only partake from rabbinically-approved food and water sources. I hoped that I as a "progressive" Jew could provide them with another perspective, and explain the behavior of the family in a way that made sense to this couple. It seems my explanation helped "humanize" the Orthodox Jews for them. In the absence of a sense-making narrative, the host family misinterpreted the behavior and came to think of all Jews in monolithic, simplistic terms - in less fully human terms - as strange and very rude. My narrative restored some of the guests' humanity in the hosts' eyes by reframing it in terms the couple could understand and respect. This type of reframing and diversity education is what interfaithers try to bring to Rome in order to humanize social actors outside the norm who are readily subject to dehumanizing stereotypes.

In the Roman context, coming to

\footnotetext{
*** Jewish dietary law, which includes the separation of plates which can hold dairy products and meat products, to ensure that never the twain shall meet.
} 
a deeper understanding of each others' motives and identifying common ground constitutes humanization, as articulated by a volunteer at Istituto Tevere: "We want people to come and know each other in an environment where people face each other, see faces and gestures....We come to the same God, and if we are white, black or blonde, it's not important. We are humans. When we are friends, we are blind to color, we don't see it. All are equal. It is with each other we are human. Dialogue is humanization. Through dialogue the others become more human. The first priority is the human being. Later come the details."

In contrast to the relatively tranquil dialogues of Rome, the work of Israel/ Palestine dialogues is to convince participants that the other is not an immediate existential threat. A volunteer at Holy Land Trust in Bethlehem described, "With these encounters you see that the other is just a human who is not going to hurt you; you see that you are safe with them."

While dehumanizing another person can fulfill a defensive, selfprotective function in the face of ominous threat, culturally and systemically engrained fear of the "other side" and perceptions of constant threat have made it more difficult for people to be open-minded or curious enough to establish commonalities. In the Middle Eastern context, dehumanization is much more apparent, in many ways the widely-sanctioned default stance when it comes to regarding the other. Standing in an olive field near Walajah, Kamila recounted a standoff of mutual dehumanization between Zionist settlers and a Palestinian.

If a settler came to me and said they wanted to seek mutual understanding? If a settler wanted to explain themselves, their motives for settling, could I listen? No. No. It is very hard to understand them. This is my home. They stole and forbid me from my own land. I cannot go to Jerusalem or into their settlement. They have taken so much and they have so much power. They have hurt us so much I cannot understand them. ...If you are using religion or a Biblical argument, you should also choose the human being. They don't respect human life. They see themselves as sons of God, and Arabs as slaves. But I don't have a high wall around my house. A wall means you know you are a thief, and you are afraid. To me they are the ones not acting human.

Khalid in Palestine experienced dehumanization when he described his feelings about the red warning signs posted on the Green Line checkpoints. The signs discourage Israelis from entering the Palestine territories because "entrance for Israeli citizens is forbidden, dangerous to your lives, and against the Israeli law."

I can't smile at those big red border signs. I'll tell you how they feel. You know those signs that people with mean dogs buy? Beware of the dog? There is a mean dog here? And you should not come in because the owner is not here and you will get bit? This is what those signs are, like we are animals in the zoo, like we are mean dogs. To be human you have to have faith in other human 
beings.

In both Rome and in the Middle East, humanizing other people seems to signify the opposite of objectifying and generalizing. The "humanity" that is revealed in the other person is an "essence" that is to be honored. And in the Middle East that human essence stands in clear contrast to its dehumanizing loss or absence. As a volunteer at a binational Arab-Israeli Olive Oil Cooperative said, "If people come and see us, they can see Jews and Arabs work together, humanize the other side, see us face-to-face, see that we don't have horns and tails." Likewise, at the Parent's Circle / Families Forum, an officer relayed that "Our purpose is to show that the other is also human and show that they suffered just as much as we do when we lose our brother, sister, son."

The notion of humanity, and how it is furthered through engagement across religious and social divides, is a discursive object of central importance in the Middle Eastern context. An Israeli woman who runs the group Road to Recovery, is persuaded that "If people recognize each other as humans, things start to change--therefore the human level is crucial." Across the border, in Palestine, a volunteer at a non-violence organization said, "We refuse to see Israelis as the enemy. Our stance is to look at them as humans, with fresh eyes, and see what we can learn from each other, because Israelis and Palestinians are interdependent and halves of the whole."

Differently from the fractious Middle East, the discourse in Rome about humanization is mostly positive, emphasizing dialogue as a modality for promoting the sacred value of humanity, rather than a modality for healing a human essence that has been injured or disregarded. For example, at a Vatican-sponsored dialogue between Christians and Buddhists, a speaker declared, "Dialogue is a way to maintain humanity in crisis," implying that participants in a Roman dialogue arrive with humanity already intact, in contrast to Middle Eastern dialogues which must first attend to the difficult task of establishing shared humanity. A Roman woman who was exposed to dialogue through a friend said "We have to look in the eyes of the other, see their skin, see yourself in the other, then we can treasure their human life like we do our own. We have the same needs: food, shelter, love, protection, to be part of a group. We have traditions, cultures, but at a basic level there's a lowest common denominator. We can hate the other, but it's hating yourself."

At a Roma Tre University conference on religion and conflict, a panel on interreligious dialogue featured a nun working in a homeless shelter run by the order started by Mother Theresa. The shelter tries to minister to a diverse population, welcoming homeless people of all religions. The sister narrated a 
process of humanization that expressed that mutual respect and relationship restore humanity.

At the heart of our dialogue is respect for the dignity of the individual. People need more than food. They need a warm smile, a personal greeting, to be called by name--these are the words of the heart. At first, those who come to us want nothing to do with us as people, but little by little they see us sisters and begin to want to know us in small ways. They change when they realize they are cared about in a personal way; they become more human. Being treated as part of the human family is healing - it makes them human. Once we cared for a Muslim lady in our community who experienced respect during her Ramadan fast, so she became respectful of Catholic women and more involved and supportive. We reached her humanity, so she reached ours.

Interfaithers are clear that recognizing the humanity of religious others is at the heart of what they are doing, but they speak about it in many ways. Some seem to define humanization as the recognition of the human rights of the other, or of the sacredness of all people, and the importance of resisting stereotypes, as a Combatants for Peace volunteer in Israel said about his group's dialogue: "This is about humanizing the other side, instead of dehumanizing them. Even terrorists were once children." Some reference the process of the other becoming more familiar, while some speak of a more distinct other. Some aim for seeing the other as more relatable and personally likable. Some of my interviewees emphasized that they consider practices of humanization to be very different from political solutions to conflict, chiefly because dialogue works "on the ground," interfacing with daily realities, where people are more likely to make personal contact and see the humanity in each other.

Underlying that range of discourse, in my observation, humanization comes in two forms: commonality-based and diversity-based.

\section{Humanization and Minimization}

Commonality-based humanization is what Milton Bennett, Mohamed Abu-Nimer and others in the field of intercultural communication might call "minimization." Interfaithers display a range of orientations on similarity and difference. The "Developmental Model of Intercultural Sensitivity"[8] posits a range of responses to diversity: from denial and isolation, to minimization, to integration and active cooperation. ${ }^{* * *}[9]$ [10]

Interfaithers rarely respond to religious difference with denial or defense (at least openly), but they almost always minimize differences by calling them "details" or "cultural variances." They often minimize by saying there is a "common truth" at the center of all religions, that religions are

\footnotetext{
**** Since Mohamed Abu-Nimer adapted Hammer and Bennett's scale specifically to discuss religious differences and interfaith dialogue, I draw on his adaptation here.
} 
all paths to a similar ultimate reality. Minimization is an assimilationist approach to difference that asks religious others to join a melting pot (rather than to add themselves to a "salad" where each individual member remains distinct) — when they say that a difference is a shield hiding real substance. Bennett breaks minimization down into categories of "physical universalism" and "transcendent universalism." An example of physical universalism is "we all live in human bodies." Transcendent universalism boils down to "all religions worship the same divine." According to transcendent universalism, all religions orbit the same transcendent reality, every religion wants the same thing, or (in its most exclusive form) everyone actually belongs to the minimizer's religion. Other examples of transcendent universalism in the interfaith world are Hans Kung's global ethic, Karen Armstrong's Charter for Compassion, praise of a universally transcendent "force" that assumes to bring us together.

Throughout the history of the dialogue movement, and today still, many interfaithers have done their humanizing by minimizing differences and asserting a universal common core. These commonality-seeking interfaithers rarely respond to religious difference with denial or defense (at least openly), but they almost always reach for what is shared rather than what is distinct. This conforms to one of Bennett's points about minimization, which is that it reduces the complexity of the other. That might seem to have some initial benefit for positive feelings about the other but becomes less adaptive over time if one needs to deepen relationships and collaboration.

The logical next question is, what constitutes this common, universalized general category of "human"? Aristotle argued that what differentiates humans from other sentient beings is that we are capable of reason.[11] But reasoning is an abstract process, and most of my interviewees seem to view the process of humanization as the establishment of very sensory, experiential commonalities, such as shared emotions or parallel family relationships. One dialoguer expressed this to me emphatically.

We're all humans. We suffer, we love, get angry, get sad. We can believe in different things, but we all have the same feelings. If we can see this, we can love each other. Ideas are different so we can't connect there. But we can connect on a human level. Religious people have a lot in common because they all believe in something. They should realize this about each other.

Shared emotions also point to shared experiences such as parenthood or friendship. At a press conference for Confronti's Semi di Pace lectures at the Italian House of Representatives, one congressman said, "The universality of parental concern can access our shared humanity, which is what we must draw 
out in order to come together and stand against what threatens us collectively."

Paolo Freire, similarly, put relationality at the heart of the process of humanization. This process is an "ontological vocation," an aspirational journey that sets Homo sapiens apart from other sentient creatures. Peter Roberts[12] says that people pursue this ideal of being human when we engage in critical, dialogical praxis. According to Freire, what makes us distinctly human is our ability to engage in intentional, relational praxis. He defines praxis as "reflection and action upon the world in order to transform it."'[13]

The essence of humanity, according to Freire, is the capacity to transform the world through reflective, critical, dialogical action.[14] The crucial element of humanizing praxis is dialogue[15] because human being is fundamentally relational; the pursuit of humanization can never be isolated or individualistic. It is only in relationship, in the social world, where we can become more fully human. "We humanize ourselves through dialogue with others."[16] Dialogue is "the encounter between [people], mediated by the world, in order to name the world."'[17] That is, the human quest to understand and transform the world, through communication with others, is a praxis which must involve a love of the world and others, along with a sense of humility and critical thinking.

In pursuit of such "humanization," dialoguers often seek consciously to discard categories like Muslim, immigrant, Bangladeshi, Arab. Giovanni from Confronti explained that categories reduce others, "instead of regarding them as people. When I label, that person before me is no longer a person, he is a label." Interfaithers consider categories to be, if not dehumanizing, at least depersonalizing. "Humanization" purports to restore individuality to the other.

There is a paradox here. While humanization is explained as a process of transcending social categories, it actually collapses all human particularity or categorizable qualities into an assumed and vague ultimate category of "human." They shed generalizations with an invocation of the ultimate generalization. Humanization represents a stance of anti-generalization achieved through the application of a generalization. The universalistic essentialization of "human" is not the same as the sociopolitical tactic described by sociologists and cultural theorists as "strategic essentialism,"[18][19] because humanization does not have to do with mobilizing a certain identity category in order to achieve political or social gain. Nevertheless, it could be helpful in the heuristic sense to think of "human" as a "strategic essentialist identity" of the interfaith society.

Humanization, then, is a normative discursive object that clearly does not 
refer to that which might be considered instinctual and natural behavior for human beings. Dialoguers who invoke the term "human" seem to refer to a romanticized essentialist human who is the embodiment of their own sacred values. In contrast, Homo sapiens have a tendency to make generalizations based on categories and to engage in conflict. Dialoguers use "human" in a normative sense, referring to transcending base instincts, and to engaging ideals and values rooted in peace. So, the humanness of dialogue is a counterpoint to the conflict and violence that may be natural to Homo sapiens. Dialoguers make this distinction as part of their vocation.

In my conversations with nondialoguers, I found that they make the same distinction. Once during my fieldwork, I found myself riding in a cab through Tel Aviv, driven by an Israeli cab driver on the way to the Ben Gurion airport. In the cab we talked about the Israeli occupation of the Palestinian territories. The cab driver said, "Conflict is natural for humans, but we can't just do what humans do. We have to be better." Translated into the parlance of this discussion, he meant that we have to be better than Homo sapiens - we have to be human.

In dialoguer discourse, the natural instincts of Homo sapiens are almost entirely negative. Homo sapiens are construed as animalistic creatures, whereas humans are construed as noble creatures of conscience and heightened consciousness of the other. In keeping with Durkheim, only when a person is immersed in a moral collective does he or she become human. A lone homo sapiens is motivated only by greed - and is, as Durkheim says, homo economicus. Dialoguers seem only to consider those who share their sacred values of unity, harmony, social change and civic society as truly reflecting the qualities of humanity. So, what about those Homo sapiens who do not share interfaith values? This is where pluralism finds its limits: if these Homo sapiens cannot be considered Humans, then dialoguers' efforts to define what is human inherently dehumanize those who do not share these values.

\section{"Unity in Diversity": The Dance of Commonality and Difference}

As we have seen, humanization, in its simplest form, is achieved through identifying commonalities. A bishop at the Vatican told me, "The highest challenge is to engage in serious search for what is in common." In this vein, humanization is a process of deepening one's familiarity with the mundane "human" details of the other's life: being a parent, enjoying certain sports or art forms, sharing a passion for The Beatles. By discussing concrete particularities, often via the telling of life stories and shared experiences, people come into awareness of their common humanity. In a conversation 
with Bill Moyers, Marshall Ganz described how "the particular then becomes the portal on the transcendent. ...Although many people associate understanding with abstraction, the paradoxical truth is just the opposite."[20]

Increasingly, however, interfaithers also speak of the value of difference. It is in the embrace of differences that humanization starts to move beyond minimization and into pluralism. As I occasionally heard in Rome's interfaith society, there is something essentially "human" in the sincere and peaceful exploration of both similarities and differences. At this time in the history of the interfaith movement, the discourse of humanization dances between invoking similarity and difference, particularity and generalization. For example, some interreligious leaders, like Daniel at the Israeli-Palestinian Interfaith Encounter Association, start groups off by emphasizing commonalities in order to relax people, and once trust has been established, the group will begin to explore their differences.

When we do interfaith dialogue, we risk not recognizing differences - to lose respect for what is really different. People have to deepen their identities, not be antagonistic to differences but be confident. They have to be able to face other identities within and beyond their own religion. The deepest value we have at Religions for Peace is respect for difference. (Volunteer, Religions for Peace)
Humanization, in its least mature and most populist form, collapses diverse categories into vague common ground. It chiefly functions to ameliorate the discomfort of alterity. Although discourse about humanization focuses initially on commonalities, dialogue also reveals the emergence of differences. One might imagine a process of seeking pluralism that begins with "commonality" approaches to humanization and eventually matures into "unity in diversity" approaches to humanization, ideally developing into an experience of mutual recognition, or the process of accepting and eventually respecting diversity.

\section{Methods of Humanization}

How might humanization come about? Dialoguers speak of the necessity of humility and learning. Giulia at Confronti reflected, "Now I have humility and knowledge, so I can say why that person wears a headscarf or why that person prays in a particular way. ....And now it's easier for me to understand the differences and see we're both just human. I can make more room for the possibility that we do not understand everything." Humanization may also entail granting the other agency to self-define, as dialoguers learn to set aside past impressions or associations and to listen with an open mind. The section below explores various routes to such humility and open-mindedness, elaborating on 
creative dialogue and non-discursive forms of interfaithing such as artistic collaboration, shared silence, humor and cognitive frame-shifting, as well as exploring the "flagship" tactic for humanization: the exchange of personal narratives.

\section{Creative Dialogue: Breaking down the Wall of Words}

Since humanization results from experiencing shared sentiments, cultivating empathy, or reflecting on common structures of human relationality such as parenthood or friendship, it follows that certain methodologies of interreligious dialogue are more likely to foster humanization than others. That is, methodologies such as theological and academic discourse are less effective, in comparison to relational and social dialogues. They are less likely to provide a paradigmatic shift in viewing the humanity of the other. Confronti contributor Maria noted, "Rational discourse is useless when it comes to changing your mind. It takes humor or friendship, something to take you out of yourself." Institutional interfaithing, especially at such a high level as the Vatican where event participants do not interact much and listen to formal panels, showcase the difference between "discourse on connecting" and "connecting." Humanization is unlikely to take place during these events, which might be termed as "meta-dialogues," but they may prepare interfaith leaders to initiate more meaningful, relational dialogues in their home communities.

Indeed, according to most of my interviewees, humanization emerges chiefly in practical, personal encounters, not in theoretical discussions. It is a subjective experience, a process to share more than a concept to grasp. Ahmet from Istituto Tevere, recalling his travel seminars with Confronti, said the trip "was important because it wasn't theoretical. It was practical." He saw how people actually live, what they eat. "Now I can understand them in a new way."

While an exchange of words particularly the exchange of personal narratives - can foster an experience of the humanity of the other, sometimes elite discourse can obscure meaningmaking and relationship building. The creative dialogue form of interfaith engagement, such as artistic collaborations or even shared humor, can potentially draw forth a spontaneous encounter of authentic humanity. Shimon of Rabbis for Human Rights said, "We can't limit dialogue to 'words' because the whole concept concerns the attitude to other, the attitude of relating to other with respect...to develop genuine friendships that don't lean on concepts, but good sincere feelings and hopes for each other."

In the same spirit, in December 2015, Istituto Tevere hosted a Concert for Peace with Christian, Jewish 
and Muslim themes. A musician I interviewed, Anna of Istituto Rinaldo Franci, spoke of music as a "universal language of unity and peace [that] offers experience that needs no mediation and can be shared. Through music, human limits leave. Music can push humans further." She also made a powerful comparison between music and dialogue.

Music is an important metaphor for dialogue. Musicians have to develop discipline, respect, and freedom to improvise--they must develop equilibrium of these qualities and between each other in order to achieve harmony. They have to listen to each other. They provide interpretations with constraints and only express themselves personally in moments when there is structured space and consensual agreement and expectation. Some have talent, others develop themselves through will. Some belong to different types of music styles, play different instruments, have different goals, are involved in different ways. Music is a dialogue.

Another musician, Fahim, confirmed this analogy. Fahim is the director and cellist of Beyond Borders, an interfaith music ensemble which plays traditional music from many traditions. They are Jewish, Catholic, Orthodox and Muslim classical musicians who play traditional classical pieces as a way of preserving them. A few months later, Fahim and I met for coffee at Largo Argentina near the Pantheon, and I asked him more about Beyond Borders. He thinks their art makes a statement "outside politics, outside religion, just music, no words, no position, just music." As Fahim described, the musicians work together to adopt a united form and play together with a higher purpose, drawing on their artistry, their training, their discipline and love of music. "The truth of the music is not rigid; it can be modified."

Beyond Borders was founded during an orchestra workshop at the Vatican. Musicians from four nations, all of different religions, gathered together to make music. They lived, worked, and ate together: Israelis, Algerians, Italians, and Greeks. "There were no conflicts, no hate. We had a higher purpose. We all had different opinions and worldviews, but we were equal and united. It was a true convivenza." The orchestral workshop culminated with the Vatican Christmas mass, "and there was no interpersonal problem at all." Fahim started to ask himself, all those wars and conflicts, where are they from? "Because it is possible to all live daily life together happily as diverse colleagues. So, I founded Beyond Borders. It is a symbol, an example of a solution." $\mathrm{He}$ pulled out his phone and showed me a YouTube video in which he plays an Arabic melody behind Pope Benedict's Christian prayer in German. "If it changes one person's mind, it is worth it," said Fahim. "It surprises people to see a Muslim playing classical music, so I change ideas just by being myself."

Humor can also provide an experience of commonality. During 
Confronti's Semi di Pace lecture series, which presents lectures from Israelis and Palestinians in Italian high schools, two Palestinian and Israeli speakers engaged in a humorous, affectionate "humanizing" exchange.

Sarah: I ordered you a double espresso, Khalid.

Khalid: How did you know what I wanted?

Sarah: You're my neighbor, I know what you want.

Khalid: I want to take my shoes off and walk on the Mediterranean Sea.

Sarah: You are not Jesus, Khalid.

Khalid: I walked on water once! When it rained. The water came from the sky and I walked right onto the concrete. You see? Miracles are self-defined.

Sarah: You have to believe in miracles if you live in the Middle East.

Humor is becoming more popular as an entrée to interfaith engagement. [21][22] ${ }^{* * * * *}$ Academics have also begun to take note. At the 2017 annual meeting of the International Society of Sociology and Religion, a program unit called "Religion and Humor" was placed within the theme of "Negotiation and Conflict." Researcher Pål Ketil Botvar called the engagement of

$* * * * *$ Other examples of humor in interfaith dialogue include Negin Farsad's "social justice comedy" at Harvard's 2016 Interfaith Comedy Hour; Rabbi Bob Alper and community activist Azhar Usman's comedy duo entitled "One Muslim, One Jew, One Stage;" comedians Scott Blakeman and Dean Obeidallah's act "Stand Up for Peace;" and Omar Regan's comedy tour FUNATICAL. religious humor a way to see things differently - which he referred to as a transformational approach of participating in interfaith dialogue. According to Botvar, comedy that reflects common foibles and humanity makes it harder for movements demeaning religious and ethnic groups to gain traction. Because of its power, however, humor must be wielded carefully in interfaith dialogue, because religious environments are notoriously sensitive. Mustafa, from Istituto Tevere, recalled, "At a dialogue in Brussels I learned the hard way how Hindus are offended daily by people eating burgers and making Gandhi jokes." If someone gets offended, the dialogue can easily be compromised. Though Botvar also acknowledges that sometimes religious humor exploits the weak and vulnerable or promotes prejudice. But, if done well, this comedic approach can also build social ties and relax anxieties, bonding diverse people together and introducing people to different cultures.[23]

Silence - found in shared prayer and meditation - is also cited as an effective mode of dialogue because it allows for connection without obstruction, supposedly allowing what is essentially "human" about each person to connect over spontaneous shared experiences of tranquility and beauty. In Rome, the co-founder of the John Cabot University Interfaith Club, describe how his students regularly meet in the meditation garden for 30 
minutes of silence, or even promote full days of silence. "Those moments are emblematic. We are being true, being human together in silence. We don't have to talk or fight or ask questions. Silence is the best interfaith prayer, so powerful and free. There are no words to confuse each other, and silence doesn't demand resolution." The John Cabot University Interfaith Club ends their meetings in silence. "It is a lack of resolution that gives us peaceful resolution." Like other methods of creative dialogue, silence literally breaks down the wall of words.

\section{Humanization and Non-Linear Thinking}

A more formal methodology for pursuing humanization is the NonLinear Thinking (NLT) method taught by Holy Land Trust (HLT) in Palestine. It exemplifies a practical process for adopting a mindset free from inhibiting categories. Non-Linear Thinking posits that the main barrier to peace and friendship is cognition: all the ways people make assumptions, project negative associations, and ascribe harmful intentions to others without basis. It clears a path for humanization because it sharpens awareness of one's own stereotypes and pre-conceptions and frees the mind into openness and shared experience.

NLT, in theory and practice, insists that it is possible for humans to experience reality unencumbered by social categories or projections. The method does not propose that humans can strip themselves of categories to the point of being left without an identity, or that it is possible to be only "humans" and nothing else, with no cultural particularity. HLT staff say that in the practice of Non-Linear Thinking these categories do not completely disappear; rather, a person develops heightened awareness of the ways in which these categories are clouding, obstructing, or unbalancing their perception of the other. It is a method, much like "mindfulness" practice, that trains people to approach the present moment - and the people who are encountered in the present moment - with impartiality and open-mindedness. They are taught to avoid projecting categorical condemnations learned from negative experiences in the past, either in one's personal history or from a larger longer historical narrative of oppression. NLT is said to free people from negative preconceptions based on personal or collective past experiences.

This method was adopted by HLT staff as part of their search for new leadership training methods. Leadership coach Miki Walleczek introduced them to the concept. Jonathan, the director of HLT, reflected, "We get so attached and connected to the past, we base everything on the past. But the past is nothing but a story. [Non-Linear Thinking] is about plucking or weaning out destructive aspects of perception. 
...I don't aim to be identity-free. But I also don't want to be imprisoned by my interpretations, so I am weaning out aspects of it that are not lifegiving." Like techniques for eliminating "implicit bias," Non-Linear Thinking offers dialoguers a tool for humanizing the religious other.

\section{Narrative as a Method of Humanization}

Perhaps the most common humanizing method in interfaith praxis is seeking commonality through the exchange of personal narratives. How do narratives, and the practice of sharing narratives, assist identity formation and the reconstruction of identities to mutually reflect each other? This is what this section will explore.

The word "narrative" has two possible meanings for the purposes of this research. It can refer to storytelling, or it can refer to grappling with the multiple accounts that can arise in a single group over a shared experience - that is, relating different perspectives about a shared experience. The methodology of engaging narratives, in both senses of the word, is believed to foster the process of humanization.

Perhaps it is best to start with a story, told by Benedetto, from the Waldensian Foundation.

When I began living in Rome in 2002 there was a boy from Cameroon who was escaped from prison. That boy made me change my opinions about Africa and immigrants. I was attending a
Methodist church at the time and we met there. One day he came to my house for lunch, he didn't have a place to stay. He always refused to stay at mine because he wanted a place just for him, but he would accept invitations for meals. That time I prepared him some pasta and some fish. He refused the fish, and I was a bit shocked, but he explained that he didn't know if the day after he could afford to eat that much, so he didn't want to get used to eating too much and too well. And he saw that I was surprised, and a little ashamed for offering too much, and he was very gentle and grateful. He saw he needed to explain himself to me instead of just refusing. So, he told me the story of where he came from and what his life had been like in Cameroon. The first opinion I changed from meeting him was the idea that everyone in Africa is very poor. This boy wasn't poor back in his country, he was an agricultural engineer and he had a degree, a job, a house, a car. I was speechless, because the life of a refugee here can be worse than the one they were living in their own country. That boy forced himself to live in poverty, just to survive. Everyone, even the Right Wing, believe the contrary. Everyone thinks that these people come here to make money and enjoy the riches of Europe. In some cases it can be true, in some others not. ...That boy changed my opinion about immigration and refugees. $\mathrm{He}$ completely changed my perspective. I thought that offering a big meal to that boy was a good thing, and instead it was against the strategy of this person who was trying to survive every day without charity, by his own power. And when he changed my expectations I saw him in a whole new light. And I think that he wasn't used to being listened to, or used to someone trying to understand what he really needs. These people should be supported and helped to achieve their life project, because they all come from different backgrounds. (Benedetto, Waldensian Federation) 
In this story, when the boy from Cameroon refuses the fish, the narrator used words like "shocked," "surprised" and "ashamed" to describe his reaction. When the boy takes the time to explain himself, the narrator listens and is asked to integrate information that is so new to him that he is struck "speechless." The boy from Cameroon adopts a "gentle and grateful" tone in his selfarticulation, mitigating the narrator's shame and staving off defensive apologies. The narrator eventually feels "that boy made me change my opinions about Africa and immigrants ... when he changed my expectations I saw him in a whole new light." In this vignette, the elements of surprise and discrepant information challenge a stereotype. The encounter with radical difference emerges through the course of the interaction, as one person gently asserts the way in which they are different from the other, and the other is able to undergo the "corrective relational experience"[24] of listening to the person, accepting their differences, and seeing him more clearly.

The trajectory of humanization through narrative often starts with telling a personal story. Many scholars have described how the act of creating and sharing a narrative helps make coherent sense of one's own identity and life journey, and how the act of telling stories creates a community. [25][26] Sigmund Freud considered psychoanalytic treatment a "talking cure," and the hallmark of dialogue is talking. Freud relied on talking to cure afflictions ranging from "paralysis, convulsions, sleep disturbances, anorexia, basil motor and respiratory ills, and many other physical and emotional conditions."[27] It follows that narrative practices in dialogue have cathartic potential. Narratives must be released in an emotional manner - that is the essence of Freudian therapy allowing speakers and listeners not just to listen rationally, but to experience. Articulation of personal narratives can benefit both narrator and listener. [28] But "humanization" is not about recitation: it occurs in the relational space that opens up when listeners are drawn into the vivid particularities of the story, told in such a way that people see each other's lives more personally.

It is therefore reasonable to frame some forms of storytelling as a form of mutual narrative therapy, for both speaker and listener, offering the cultivation of intimacy and empathy. Storytellers experience recognition through telling their story, while listeners experience an expansion of perspective, and both experience relationship.

Symbolic interactionist George Herbert Mead[29] wrote that communication forms the self and directs the process of cooperative activity. Communication is the organizing principle of the community. Communication theorist Em Griffin 
summarized Mead's main argument by saying, "the most human and humanizing activity that people engage in is talking to each other." This emphasis on talking is, if not culturally universal, certainly prevalent in the interfaith society. Mead argued that humans are created through social interaction, and that language is the principle of social organization which has made the distinctively human society possible. Social interaction is the source of meaning, and for symbolic interactionists, interaction is the basic unit of study, because individuals are created through interaction - the self is the result of the social process of communicating with others. Society too is created through social interaction, as individuals communicate and take on each other's roles and values. If Mead had lived long enough to see the interfaith dialogue movement, he might have been pleased.

The ideal of human society is one which does bring people so closely together in their interrelationships [through] the necessary system of communication.... The development of communication is not simply a matter of abstract ideas, but is a process of putting one's self in the place of the other person's attitude. ...The ideal of human society cannot exist as long as it is impossible for individuals to enter into the attitudes of [others].[31]

From the standpoint of symbolic interactionism, it is therefore not a big leap to make the connection between narrative and humanization. Storytelling and listening, then, can be understood to work in tandem to reinforce the "new consciousness" that dialoguers hope their practices will introduce, engaging communication that allows individuals, in Mead's words, to put themselves "into the attitudes of others."

During my fieldwork, I traveled three times with five other delegates of Confronti to the Palestinian territories. Each trip was planned around the notion that we would be listeners who could record and then pass on the stories we heard. According to the Confronti trip planners, our stories would help to humanize the people we met for any public audience that might hear them. Indeed, the motto of many of the peace organizations we visited was "Come and see; then go and tell." In the poorest and most violent settings of Palestine, when we spoke with individuals and asked how we could help alleviate their suffering, many replied, "Just tell my story." Their request was made with the faith that their story will allow new listeners to put themselves "into the attitudes of the others."

Their responses reflect the humanization potential of narrative: these stories are believed to have power to reverse prevailing negative stereotypes of Palestinians and help change the public narrative about the Arab-Israeli conflict. In fact, changing the public narrative is one of the hoped-for signs of success in interfaith dialogue. A shifting public narrative about a certain community signifies 
that the community itself is entering the process of co-constructing their identity and image, instead of being passive while they are talked about. If a community assumes the power of self-definition, and their self-articulated vision is absorbed into broader public discourse, the interaction with the wider world can transform. Giovanni from Confronti described his experience of this kind of change when he said, "In dialogue the thing that is different over time, the thing that can really change, is the way we talk about immigration, ethics, politics, et cetera. If dialogue works, you will talk in different ways over time."

Stories are never simple, however. Awareness of multiple narratives about similar topics is another path toward humanizing the other. In recent years, the focus on juxtaposing and exploring "multiple narratives" has become a chief methodology in the practice of dialogue. This is why the Parent's Circle/Families Forum started their Narratives Project. It is based on the belief that people see the same history through different eyes. This project strives to bring the two together: "You don't need to adopt or believe the other's narrative but you need to acknowledge his existence and respect it and all the necessities and desires that come with that history," said Doubi, director of the organization. Raising awareness that experiences are recalled from multiple perspectives, and that there is never one single narrative of any given reality, can alone constitute a paradigmatic shift for a person who previously believed their narrative to be the defining one. The possibility of multiple narratives creates room for different people and different perceptions to become comprehensible. One may disagree with a counter-narrative, but dialoguers still believe that the very introduction of a plausible new story makes the other person less subject to stereotyping, fear or wholesale dismissal. Disconfirming stereotypes and humanizing the other by allowing for their uniqueness and complexity, reframes one's perspective and also provides a basis for new behaviors.

A Holy Land Trust guide took our Confronti group to visit a landowner in Walajah, who told the story of his disputed property. He is living in the last standing homestead in a oncethriving Palestinian town which has been encroached upon by the Israeli settlement Har Gilo. His house was built between 1948 and 1967, so it is technically a legal homestead, but he told us his family is under constant pressure from the Israeli Ministry of the Interior and the municipality of Jerusalem to vacate. I asked the man what it meant for him to have visitors who can listen to his story. His response connected humanization and narrative.

It is the most important thing. People in the world trust and believe the media. But if you talk with a sister or a friend and you tell them about 
me here in Walajah, they will see your eyes and know what you have seen. That has stronger power than any media. You are an ambassador. You are a messenger. You make us humans in the eyes of the world.

The power of narrative to "make us human" is why storytelling is the mission of Confronti's Beyond the Wall project. They seek to foster relationships and personal encounters so that visitors can hear Palestinian realities in order to disconfirm stereotypes. Travelers and writers with Confronti are ambassadors who listen and personally connect and try to help Palestinians transmit their stories to the world.

Dialoguers say that the practice of telling one's own story and listening to the stories of others is an effective modality for the kind of humanization that includes acceptance of difference. They also say that effective interfaith engagement is built on the practice of humanization, and that storytelling exchanges facilitate shared emotions and experiences while introducing elements of deep difference. Dialoguers say stories make possible a dawning consciousness that, even though we are different in some ways, we are also all struggling, suffering people sharing this world together. Difference is one of the barriers that leads most quickly to human alienation. According to dialoguers, when radical difference rears its head, stories pave the way for mutual humanization.

\section{Conclusion}

This article has explored through transcultural ethnographic data sources the interfaith construct of humanization. Through this data we can see that "humanization" is a common discursive goal of dialoguers. In Italy, humanization is a matter of disconfirming stereotypes and alleviating ignorance across social divides, whereas in the Middle East humanization intensifies into a commitment to not physically harm the other, who is recognized through intergroup engagement as fully human. Humanization enables its practitioners to become more fully human, in each other's eyes and also in the sense of their innate potential, because humanity is relational. Humanization occasionally surfaces as the minimization of intergroup differences in the name of identifying common ground, but it also describes a shifted perspective of the other which is respectful of differences. Humanization can be achieved through non-discursive relational practices such as artistic collaboration, shared silence, humor or cognitive re-framing, but most often through narrative storytelling. Narrative dialogue - both storytelling and raising awareness of the multiplicity of perspectives on reality - often leads to an experience of shared humanity. Finally, humanization is another discursive object that dialoguers invoke to enhance group solidarity and express collective identity in the form of their 
sacred values. By frequently invoking

the concept of humanization, interfaith

dialoguers signal to each other that they

are uniting around a common goal.[]

\section{References}

[1] Agee, Jane. "Developing Qualitative Research Questions: a Reflective Process." International Journal of Qualitative Studies in Education, vol. 22, no. 4, 2009, pp. 431447.

[2] Robinson, Oliver C. "Sampling in Interview-Based Qualitative Research: A Theoretical and Practical Guide. Qualitative Research in Psychology, vol. 11, no. 1, 2013, pp. 2541.

[3] Browne, Kath. "Snowball Sampling: Using Social Networks to Research NonHeterosexual Women.” International Journal of Social Research Methodology, vol. 8, no. 1, 2005, pp. 47-60.

[4] Geddes, Alistair, et al. "When the Snowball Fails to Roll and the Use of 'Horizontal' Networking in Qualitative Social Research." International Journal of Social Research Methodology, 2017, pp. 1-12.

[5] Durkheim, Èmile. The Elementary Forms of the Religious Life. Free Press, 1912, pp. 420-421.

[6] Durkheim, Emile. "Individualism and the Intellectuals." Durkheim on Religion, edited by W.S.F Pickering, London, Routledge \& Kegan Paul, 1975, pp. 59-73.

[7] Freire, Paulo. Pedagogy of the Oppressed. Penguin Group, 1972, p. 57.

[8] Hammer, Mitchell, Milton Bennett and R. Wiseman. "Measuring Intercultural Sensitivity: The Intercultural Development Inventory." International Journal of Intercultural Relations, vol. 27, no. 4, 2003, pp. 421-443.

[9] Abu-Nimer, Mohammed. "Conflict Resolution, Culture, and Religion: Toward a Training Model of Interreligious Peacebuilding.” Journal of Peace Research, vol. 38, no. 6, 2001, pp. 685-704

[10] Morgan, Jonathan, and Steven J. Sandage. “A Developmental Model of Interreligious Competence." Archive for the Psychology of Religion, vol. 38, no. 2, 2016, pp. 129158.

[11] Thomson, J. A. K., and Aristotle. The Ethics Aristotle: the Nicomachean Ethics. Penguin, 1976, p. 1098.

[12] Roberts, Peter. "Knowledge, Dialogue, and Humanization: The Moral Philosophy of Paulo Freire." The Journal of Educational Thought (JET) / Revue De La Pensée Éducative, vol. 32, no. 2, 1998, pp. 95-117.

[13] Freire 1972, 28.

[14] Freire, Paulo. "Showing a Man How to Name the World." New World Outlook, Aug. 1970, pp. 16-17.

[15] Freire 1972, 97.

[16] Roberts 1998, 105.

[17] Freire, 1972, 61. 
[18] Spivak, Gayatri Chakrovotry. "Strategic Essentialism." The Concise Encyclopedia of Sociology, Edited by George Ritzer and J. Michael. Ryan, John Wiley \& Sons, 2010, p. 193.

[19] Abraham, Susan. "Strategic Essentialism in Nationalist Discourses: Sketching a Feminist Agenda in the Study of Religion." Journal of Feminist Studies in Religion, vol. 25, no. 1, 2009, p. 156.

[20] Moyers, Bill, and Marshall Ganz. "Moyers: How Storytelling Is at the Heart of Making Social Change." Alternet, Http://Billmoyers.com/, 13 May 2013, www.alternet.org/ activism/moyers-how-storytelling-heart-making-social-change. Accessed 18 Apr. 2017.

[21] Ingram, Bruce. "Interfaith Comedy Show Takes a Stand." Chicagotribune.com, 21 Oct. 2015, www.chicagotribune.com/ct-hpn-go-whats-so-funny-tl-1022-20151021-story. html.

[22] Kustanowitz. "Jewish Humor Central." Rabbi Comedian Leads Stand-up Humor Workshop For Interfaith Clergy, 2010, www.jewishhumorcentral.com/2010/10/rabbicomedian-leads-stand-up-humor.html.

[23] Briggs, David. "Not Just A Joke: Studies Reveal How Religious Humor Can Break Through Prejudice.” The Huffington Post, 21 July 2017, http://www.huffingtonpost.com/entry/ not-just-a-joke-studies-reveal-how-religious-humor_us_596f7263e4b07f87578e6d7f.

[24] Sandage, Steven, et al. "Relational Spirituality and Transformation: Risking Intimacy and Alterity." Journal of Spiritual Formation and Soul Care, vol. 1, no. 2, 2008, pp. 182-206.

[25] Ammerman, Nancy T. "Religious Identities and Religious Institutions." Handbook of the Sociology of Religion, edited by Michele Dillon, Cambridge University Press, Cambridge (GB), 2004, pp. 207-224.

[26] Gill, Scherto. "Universities as Spaces for Engaging the Other: A Pedagogy of Encounter for Intercultural and Interreligious Education." International Review of Education, vol. 62, no. 4, 2016, pp. 483-500.

[27] Bucci, Wilma. "The Power of the Narrative: a Multiple Code Account." Emotion, Disclosure and Health, edited by James Pennebaker, American Psychological Association, 2006, pp. 93.

[28] Pennebaker, James W. "Writing About Emotional Experiences as a Therapeutic Process." Psychological Science, vol. 8, no. 3, May 1997, pp. 162-166.

[29] Mead, George Herbert., et al. Mind, Self \& Society: The Definitive Edition. University of Chicago Press, 2015 (1934).

[30] Griffin, Emory A. A First Look at Communication Theory. McGraw-Hill Higher Education, 2003, p. 60.

[31] Mead 1934, 147. 